\title{
Erratum to: Reform Drivers and Reform Obstacles in Natural Resource Management: The Northeast Atlantic Fisheries from 1945 to the Present
}

Stig S. Gezelius • Jesper Raakjær •

Troels Jacob Hegland

Published online: 14 September 2010

(C) Springer Science+Business Media, LLC 2010

Erratum to: Hum Ecol

DOI 10.1007/s10745-010-9337-z

Volume 38 Issue 4 Pages 471-483

The original version of this article unfortunately contained a mistake.

The information about the corresponding author's institutional affiliation was removed before printing. The correct data for authors' institutional affiliations are as follows:

Stig S. Gezelius

Norwegian Agricultural Economics Research Institute,

Oslo, Norway.

e-mail: stig.gezelius@nilf.no

Jesper Raakjær and Troels Jacob Hegland

Innovative Fisheries Management,

Hirtshals, Denmark.

The online version of the original article can be found at http://dx.doi. org/10.1007/s10745-010-9337-z.

S. S. Gezelius $(\bowtie)$

Norwegian Agricultural Economics Research Institute,

Oslo, Norway

e-mail: stig.gezelius@nilf.no

J. Raakjær • T. J. Hegland

Innovative Fisheries Management,

Hirtshals, Denmark 